Katarina Begović Univerzitet u Beogradu Filološki fakultet Srbija katarina.v.begovic@gmail.com
DOI: https://doi.org/10.18485/slovenika.2020.6.1.4

UDK: 811.163.41'371.3

811.163 .6 '373.3

811.163.41:811.163.6

Naučni članak

\title{
Bojati se (plašiti se, čuvati se, bežati od) koga/čega kao (od) <živog> ognja (<žive> vatre): srpsko-slovenačke paralele i opšti slovenski plan ${ }^{1}$
}

\section{Sažetak}

Predmet rada jeste frazeologizam bojati se (plašiti se, čuvati se, bežati od) koga/čega kao (od) <živog> ognja (<žive> vatre) u slovenskim jezicima, s posebnim osvrtom na srpski i slovenački plan. Korpus je ekscerpiran iz različitih opštih i frazeoloških leksikografskih izvora. S obzirom na dijahronijsko usmerenje istraživanja, korišćeni su i savremeni i istorijski rečnici. $\mathrm{Na}$ osnovu ekscerpiranog materijala i dosadašnjih metodoloških postupaka za utvrđivanje starine frazeologizma, ostavlja se mogućnost pretpostavci da je frazeološka jedinica nasleđena iz praslovenskog jezika. Metodologijom strukturno-semantičkog modeliranja predlaže se motivaciona baza koja podleže frazeologizaciji. Razmatraju se specifičnosti srpskog i slovenačkog korpusa $\mathrm{u}$ odnosu na ostale slovenske jezike. Posebnu pažnju u radu zavređuju i lekseme oganj i vatra, kao i sintagme živi oganj i živa vatra, koje se razmatraju kao motivacija za analiziranu frazeološku jedinicu.

Ključne reči: bojati se (plašiti se, čuvati se, bežati od) koga/čega kao (od) <ži$v o g>$ ognja (<žive> vatre), živi oganj / živa vatra, dijahronijska frazeologija, rekonstrukcija, strukturno-semantičko modeliranje

\footnotetext{
${ }^{1}$ Rad predstavlja prerađeni i dopunjeni deo $(4,2 \%)$ doktorske disertacije odbranjene 24. februara 2020. godine na Filološkom fakultetu Univerziteta u Beogradu.
} 


\section{Uvod}

Od sredine 20. veka i radova V. V. Vinogradova ${ }^{2}$ koji su utrli put frazeologiji kao samostalnoj naučnoj disciplini, razvijaju se različiti filološki, lingvistički i interdisciplinarni teorijsko-metodološki okviri analize frazeoloških jedinica.

Kada se sagleda istorija ove lingvističke discipline (Teliîa 1996, Zykova 2015), zaključuje se da je interesovanje za frazeologiju naročitu ekspanziju doživelo s razvojem antropološke naučne paradigme. Izučavanja „čoveka u jeziku i jezika u čoveku“ (Maslova 2007, 6) frazeološki korpus sagledavaju kao ključan nosilac kulturne informacije etno-nacionalne zajednice koja se određenim jezikom služi. D. Mršević-Radović podseća na to da se „odavno [...] u nauci gleda na frazeologiju kao na jedan od najvažnijih izvora za rekonstrukciju jezičke slike sveta" (Mršević-Radović 2014, V). Dekodiranje frazeološkog korpusa u istraživanjima jezičke slike sveta podrazumeva korišćenje etnoloških, mitoloških i drugih, u širem smislu kulturoloških podataka. Frazeologija je u tom svetlu nužno interdisciplinarna, a njenu intradisciplinarnost N. Vulović $(2015,19)$ ističe time što se „frazeološki fond može posmatrati kao zajedničko polje proučavanja i u kognitivnoj lingvistici i u lingvokulturologiji i u etnolingvistici“. ${ }^{3}$

Obilje različitih pristupa frazeologizmima (strukturno-semantički, kognitivni, pragmatički, etnolingvistički, lingvokulturološki itd.) nudi raznovrsne metodološke postupke analize. Međutim, čini se da je istorijska frazeologija slovenskih jezika uglavnom ostajala po strani istraživačima (Mokienko 1989, 4).

B. A. Larin $(1977,127)$ prvi je definisao zadatke istorijske frazeologije:

[...] надо выработать ясную и стройную схему для систематизации фразеологических словосочетаний, надо выяснить их образование и историю, надо уловить закономерность их появления и отмирания, удельный вес и соотношение с другими выразительными средствами языка. ${ }^{4}$

\footnotetext{
${ }^{2}$ Uр. Основные понятия русской фразеологии как лингвистической дисциплины (1946), Об основных типах фразеологических единиц в русском языке (1947), Основные типы лексических значений слова $(1953)$ (Barčot 2017, 15).

${ }^{3}$ Uobičajeno je mišljenje slovenske lingvistike, zasnovano na stavovima V. N. Telije i N.I.Tolstoja, da lingvokulturologija proučava fenomen jezika i kulture na savremenoj, a etnolingvistika na dijahronijskoj ravni. Međutim, različiti istraživači upozoravaju na to da je sam odnos lingvokulturologije i etnolingvistike nešto složeniji s obzirom na definiciju opsega interesovanja ovih disciplina (Dragićević 2010,9).

4 „Treba razraditi jasnu i logičnu shemu za sistematizaciju frazeoloških sintagmi, treba ustanoviti njihovo obrazovanje i istoriju, treba razumeti zakonitosti njihovog pojavljivanja i izumiranja, njihovu specifičnu težinu i međuodnos s drugim izražajnim sredstvima jezika“" (prevela K. B.).
} 
V. M. Mokijenko je zatim nizom istraživanja utemeljio teorijsko-metodološki aparat istorijske frazeologije na metodološkom postupku strukturno-semantičkog modeliranja. ${ }^{5} \mathrm{U}$ vezi sa ovim teorijsko-metodološkim okvirom proučavanja frazeologizama, jedno od aktuelnih pitanja istorijske frazeologije jesu i utvrđivanje starine frazeologizma i rekonstrukcija praslovenskog frazeološkog fonda (Tolstoj 1995, 75-100; Walter i dr. 2018).

\section{Predmet istraživanja}

Predmet našeg rada jeste dijahronijska analiza frazeologizma bojati se (plašiti se, čuvati se, bežati od) koga/čega kao (od) <živog> ognja (<žive > vatre $)^{6} \mathrm{u}$ srpskom i slovenačkom jeziku sa osvrtom na širi slovenski plan. Naime, posmatrajući srpski jezički materijal u širem (južno)slovenskom kontekstu, primetili smo izoglose koje, s jedne strane, spajaju opšteslovenski jezički i etnokulturni prostor, a sa druge, predstavljaju specifičnosti jednog dela zapadnojužnoslovenskog areala. ${ }^{7}$

Korpus je ekscerpiran iz 24 leksikografska i frazeografska izvora slovenskih jezika. ${ }^{8}$ Ovime je pokriven najveći deo prostora koji pripada slovenskom etnosu: srpski (i hrvatski), ${ }^{9}$ slovenački, bugarski, makedonski, ruski, beloruski, ukrajinski, poljski, češki, slovački i gornjolužičkosrpski. ${ }^{10}$

\footnotetext{
${ }^{5}$ V. M. Mokijenko je izuzetno plodan autor, a za teorijsko-metodološke postavke istorijske frazeologije naročito su značajne dve njegove monografije: Славянская фразеология (1980) і Образы русской речи, Историко-етимологические очерки фразеологии (1986). Sam autor (Mokienko 2007, 3) ističe da knjige, zajedno sa prvom u nizu - В глубь поговорки, Рассказы о происхождении крылатых слов и образных выражений (1975), predstavljaju prirodnu celinu u istorijskim frazeološkim istraživanjima.

${ }^{6}$ Korišćene zagrade $u$ vezi sa frazeološkom strukturom predstavljaju: (-) varijante leksema članova frazeološke jedinice; <-> fakultativni član frazeološke jedinice; [-] pretpostavljeni deo motivacione baze.

${ }^{7}$ Konsultovani čakavski dijalekatski izvori ne beleže analizirani frazeologizam.

${ }^{8}$ Treba imati u vidu da je konsultovano daleko više izvora, pre svega dijalekatskih i istorijskih izvora slovenskih jezika. U njima frazeologizam nije zabeležen.

${ }^{9}$ Termin 'hrvatski' daje se u zagradi kada se odnosi na književnojezički fenomen nastao u 19. veku na temelju istočnohercegovačkog dijalekta, u doba nacionalnog preporoda, strukturno i semantički komplementaran sa srpskim književnim jezikom $\mathrm{u}$ izučavanom predmetu istraživanja.

${ }^{10} \mathrm{Nije}$ konsultovana rusinska, gradišćanskohrvatska, moliska, kašupska, slovinjska, polapska i sl. korpusna građa.
} 


\section{Izazovi istorijskog frazeološkog korpusa}

2.1. Frazeologizam bojati se (plašiti se, čuvati se, bežati od) koga/ čega kao (od) <živog> ognja (<žive> vatre) posvedočen je u odgovarajućim frazeološkim varijantama širom opšteslovenskog prostora; ovde navodimo neke od pronađenih potvrda u savremenim leksikografskim izvorima:

(1) srp. (i hr.) „бојати се (чувати се) чега као живе ватре“ (РMC, s. v. жив);

(2) sloven. „paziti se (bati se) koga/česa kakor živega ognja“ (Keber 2015, s. v. ogenj);

(3) bug. „Бягам (пазя се) като од огън. Разг.; Отбягвам се като од огън. Остар. и диал.“ (РБЕ, s. v. огън);

(4) mak. „Бега како от оган“ (ДРМЈ, s. v. оган);

(5) rus. „Бояться кого-, чего-л. как огня (очень сильно). Бежать от кого-, чего-л. как от огня (стремительно, быстро)“ (БTC, s. v. огонь);

(6) ukr. „Боятися (стерегтися) як вогню“ (СУМ, s. v. вогонь);

(7) bel. „Баяцца як агню“ (Скарник, s. v. агонь);

(8) polj. „bać się jak ognia; stronić jak ognia“"(SJP, s. v. ogień);

(9) češ. ,jako ohně jsme se ho báli. Jir. Hist.“ (PSJČ, s. v. oheň);

(10) slov. „bát sa niečoho ako ohňa“ (SSJ, s. v. oheň);

(11) gornjoluž. „bojeć so kaž wohnja něčeho“ (s. v. woheń, Ivčenko i dr. 2004).

2.2. Za najstariji primer upotrebe na slovenskom prostoru uzima se primer iz građe M. Divkovića posvedočen u RJA:

(1) „Svega se ovoga imamo čuvati ... kako ogńa živoga. Divković nauk 126a" (1611) (RJA, s. v. ̌̌iv).

Kao deo istorijskog korpusa frazeologizam beleži i ruski istorijsko-etimološki frazeološki rečnik u varijanti „бежать как от огня“ (Birih i dr. 2005, s. v. огонь).

Frazeologizam ne beleže ostali konsultovani istorijski izvori, ali treba imati $u$ vidu da to ne odriče nužno starinu frazeološkoj jedinici.

2.3. Naime, konotativnost je kategorijalna osobina frazeološke jedinice prema kojoj se one razlikuju od drugih ustaljenih leksičkih spojeva (Melerovich i dr. 2008, 51-60). V. N. Telija (Teliâa 1996, 107) pod konotacijom podrazumeva pragmatičku komponentu koja dopunjuje denotativno i gramatičko značenje asocijativnim znanjem - iskustvenim, kulturno-istorijskim, znanjem određenog pogleda 
na svet, racionalno-ocenjivačkim ili emocionalno-ocenjivačkim stavom govornika prema označenom itd. Direktna posledica konotativnosti frazeološke jedinice jeste njena ekspresivna funkcija u jeziku. Frazeološka jedinica ima i ekspresivnu i nominacionu funkciju, s tim što je njena ekspresivna funkcija primarna u odnosu na nominacionu, koja podrazumeva eksplikaciju denotata.

S obzirom na to da osnovna funkcija frazeološke jedinice leži u njenoj sekundarnoj nominaciji (Mršević-Radović 1987, 15-20; Vulović 2015 , 98-103), za istraživača posvedočenost u istorijskom korpusu ne treba biti condicio sine qua non u frazeološkoj analizi. Frazeologizam ili leksički spoj koji se rekonstruiše kao motivaciona baza frazeološke jedinice poreklom iz narodnog jezika trebalo bi tražiti pre svega $u$ dijalekatskim izvorima.

2.4. Međutim, i tu se istraživač često suočava sa nedostatkom frazeološkog korpusa. Svi su dijalekatski rečnici u srpskoj leksikografiji diferencijalni u odnosu na Srpski rječnik (1818), a neki čak i u odnosu na RSA (Vučković 2013, 8-10). Slično stvari stoje i u slovenačkoj dijalekatskoj leksikografiji - ona je bar delimično diferencijalna u odnosu na Slovar slovenskega knjižnega jezika. ${ }^{11}$ N. I. Tolstoj naglašava i da oni dijalekatski rečnici koji beleže frazeološki materijal fiksiraju materijal u vezi sa svakodnevnim životom i proizvodnjom, a retko beleže klišee, formule i idiome $u$ vezi sa mitološkim predstavama i verovanjima, narodnim kalendarom i sl. (Tolstoj 1995, 65-66).

2.5. Bez obzira na navedene nedostatke istorijskog frazeološkog korpusa, ova pojava u narodnom jeziku nije ostala bez traga.

Prvo, pažnju privlače kvalifikatori u Akademijinom rečniku bugarskog jezika, koji govore o pripadnosti frazeologizma narodnom korpusu: „Бягам (пазя се) като од огън. Разг.; Отбягвам се като од огън. Остар. і диал.“ (istakla К. В.), sa odabranim primerom upotrebe - „Сляпото и рабско подражание е в състояние да убие всеки талант. Ония, които усещат в себе си зърно талант, трябва да се пазят от него като от огън. К. Величков, ПССъч. VIII, 62“ (PБE, s. V. OгъH).

\footnotetext{
${ }^{11}$ S obzirom na to da je slovenački književni jezik nastao na osnovici donjoštajerskog dijalekta, konsultovani su sledeći dijalekatski rečnici kao dopuna građi rečnika slovenačkog književnog jezika: Črnovrški dialekt (Tominec 2015), koji pripada rovtarskom dijalektu; Slovar bovškega govora (Ivančić Kutin 2015), koji pripada primorskom dijalektu; Kostelski slovar (Gregorič 2015), koji pripada dolenjskom dijalektu; Teoretični model za izdelavo strokovnega narečnega slikovnega slovarja (Benko 2013) - istraživanje je sprovedeno na materijalu koruškog dijalekta. Frazeologizam paziti se (bati se) koga/česa kakor živega ognja u konsultovanim izvorima nije posvedočen.
} 
Drugo, Divkovićev Наук крстјански за народ словински (1611) pisan je narodnim jezikom (Gabrić-Bagarić 2013, 7).

Pošli smo od pretpostavke da je frazeologizam potekao u narodnom izrazu širom slovenskog prostora - tome u prilog govore potvrde $u$ različitim slovenskim jezicima (Walter i dr. 2018, 331-332) i odsustvo potvrda u zapadnoindoevropskim jezicima, koje bi svedočile o potencijalnom slovenskom kalkiranju (Tolstoj 1995, 82).

\section{Strukturno-semantički model frazeološke jedinice}

3.1. Frazeologizam bojati se (plašiti se, čuvati se, bežati od) koga/čega kao (od) <živog> ognja (<žive> vatre) jeste komponentni poredbeni frazeologizam. ${ }^{12}$ Predstavlja realizaciju strukturno-semantičkog modela 'glagol $u$ nefrazeološkom primarnom značenju + rekcijska dopuna: nepravi objekat + poredbena odredba (nosilac frazeologizacije)'. Osnova poređenja iskazana je primarnim leksičkim značenjem, a poredbena odredba je nosilac frazeologizacije $i$ ima ulogu intenzifikatora realizovanog glagolskog značenja - može se zameniti prilogom za količinu mnogo/veoma (Vulović 2015, 200). Frazeologizacija se ostvaruje poređenjem na skali intenziteta. Frazeologizam nije idiomatičan jer leksičke komponente u njegovom sastavu nisu desemantizovane (Marjanović 2017, 151-153). Odlikuje ga živa unutrašnja forma. Ima smanjenu ekspresivnost (up. Mršević-Radović 1987, 96-97) bez pridevske komponente, a sa pridevom živ u funkciji intenzifikatora frazeološkog značenja ekspresivnost se pojačava. ${ }^{13}$ Kako se vidi iz uporednog korpusa slovenskih jezika, pridev živ je obavezan član poredbene jedinice samo na srpskom (i hrvatskom) i slovenačkom prostoru.

Ono što privlači pažnju kod poredbenih frazeologizama jeste činjenica da je nosilac frazeologizacije sintaksička jedinica $u$ funkciji odredbe. U procesu frazeologizacije ona postaje obavezna na strukturno-sintaksičkom planu i time formira frazeološki model koji podrazumeva tematsko-rematsku strukturu (Vulović 2015, 183, 186).

Relativna ustaljenost frazeologizma, koja rezultira frazeološkom varijantnošću (Mokienko 1989, 29-37), izražena je sinonimima bojati se i plašiti se, a onda i leksemama iz srodnog semantičkog

\footnotetext{
${ }^{12}$ Pregled autora koji su se bavili poredbenim frazeologizmima kod Srba i Hrvata daje S. Marjanović (2017, 142-149).

${ }^{13}$ Pridev živ sistemski se ponaša kao intenzifikator (i kvalifikator) u određenim strukturno-semantičkim modelima u srpskom (i širem slovenskom) frazeološkom korpusu (up. Begović 2019).
} 


\section{K. Begović \\ Bojati se (plašiti se, čuvati se, bežati od ...}

polja širom slovenskog prostora: čuvati se, paziti se, bežati (od), i to prema metonimijskom modelu POSLEDICA ZA UZROK. ${ }^{14}$ Stabilnost frazeološkog modela ogleda se, osim u petrificiranoj poredbenoj strukturi, u nepravim povratnim glagolima ili neprelaznim glagolima sa zajedničkom semantičkom komponentom 'strah', koji u različitim slovenskim jezicima traže rekcijsku dopunu u genitivu, sa izuzetkom bugarskog i makedonskog jezika sa analitičkom deklinacijom kao posledicom pripadnosti balkanskom jezičkom savezu. Osim neophodne kongruencije, koja podrazumeva podršku okruženja, nepravi objekat predstavlja leksikalizovanu podršku konteksta za realizaciju frazeologizma.

Treba dodati da je posledica leksičkog variranja u opisanom frazeološkom modelu i formiranje šire frazeosheme (Mokienko 1989, 33-36) iste sintaksičke strukture, ali sa nešto drugačijom frazeološkom slikom, up. plašiti se koga/čega kao <živog (samog)> đavola (vraga). Frazeoshemu odlikuje opisana sintaksička struktura - 'glagol u nefrazeološkom primarnom značenju + rekcijska dopuna: nepravi objekat + poredbena odredba (nosilac frazeologizacije)'. Poredbeni deo te strukture izražava apstrahovani semantički obrazac, koji bi se mogao definisati na sledeći način: 'intenzitet straha izriče se izazivačem straha'.

3.2. N. Vulović podseća da je „poređenje iskonski, univerzalni način upoznavanja, spoznavanja, tumačenja i opisivanja sveta, pojava i dešavanja u njemu i oko njega" (Vulović 2015, 183). D. Mršević-Radović $(1987,42)$ ističe da se frazeološkim poređenjem ,jedan pojam želi da okvalifikuje, učini poznatijim dovođenjem u vezu po nekoj osobini s poznatijim pojmom, kod kojeg je ta osobina izražena u velikom stepenu i opštepoznata“. Zato i ne čudi sužavanje osobina pojma izraženog imenicama oganj/vatra u frazeološkoj transpoziciji na univerzalnu karakteristiku - vatra je opasna.

Značajna za frazeološku rekonstrukciju jeste dalja analiza motivacione baze koja u semantičkoj transpoziciji indukuje frazeološku sliku vatrena stihija sa značenjem 'veoma velik strah'.

U ruskom istorijsko-etimološkom frazeološkom rečniku motivacija frazeologizma objašnjava se dokazivanjem nevinosti na taj način što je optuženi stavljao ruku u vatru (Birih i dr. 2005, s. v. огонь),

\footnotetext{
${ }^{14} \mathrm{O}$ važnosti datog modela za leksički dinamizam glagolske komponente govori i sama polisemija glagola bojati se - D. Mršević-Radović $(2014,189)$ primećuje da se glagol realizuje u značenju afektivnog stanja straha, ali i u značenju probuđenog mehanizma odbrane, koji podrazumeva bežanje od opasnosti.
} 
dok se $\mathrm{u}$ Keberovom frazeološkom rečniku motivacija za frazeološko poređenje objašnjava strahom od vatrene stihije uopšte: „Primera bati se koga/česa kakor živega ognja temelji na dejstvu, da je ogenj ob vsej koristnosti lahko tudi človeku zelo nevaren, zlasti nekontroliran, tj. v požarih ipd.“ (Keber 2015, s. v. živ).

Razmatrana frazeološka slika mogla bi biti motivisana i biblijskom predstavom Boga, up.:

(1) „Знај дакле данас да је Господ Бог твој, који иде пред тобом, огањ који спаљује; Он ће их истребити и Он ће их оборити пред тобом, и изгнаћеш их и истребити брзо, као што ти је казао Господ“" (Пета књига Мојсијева 9, 3);

(2) „Јер Бог наш је огањ који спаљује“ (Јеврејима посл., 12, 29).

S obzirom na značenje imeničke komponente kojom se izražava prouzrokovač straha u srpskoj frazeologiji, D. Mršević-Radović izdvaja tri poredbena strukturno-semantička modela - „vatreni“, „epidemijski“ i „magijsko-religijski“ (Mršević-Radović 2014, 190). Za nas je naročito važan upravo „vatreni“, čiji je glavni predstavnik frazeologizam bojati se (plašiti se, čuvati se, bežati od) koga/čega kao (od) <živog> ognja (<žive> vatre). Autorka motivaciju za „vatreni“ prouzrokovač straha vidi u predstavi vatre kao najjače čistilišne sile, kao i u strahu od personifikovane vatrene stihije koja guta ili proždire. S tim u vezi, obimna etnološka, mitološka i etimološka literatura pokazuje da vatrena stihija u slovenskoj duhovnoj kulturi predstavlja emanaciju solarnog božanstva, koja se, zajedno sa drugim ie. mito-religijskim predstavama, može pratiti sve do pie. plana (Loma 2005).

Kada se uzmu u obzir navedene mogućnosti za interpretaciju vatre kao prouzrokovača straha, motivaciju za strah od vatrene stihije najpre bi trebalo tražiti u njenoj oboženoj predstavi potekloj iz kulta vatre. U prilog tome govori i semantika sintagme živi oganj / živa vatra, posvedočena kao deo frazeologizma u srpskom i slovenačkom korpusu. 


\section{4. Živi oganj / živa vatra kao potencijalni nosioci frazeologizacije}

4.1. Kult vatre je univerzalan za sve primitivne i danas civilizovane zajednice. Uporedna istorijska, arheološka, etnološka i kulturološka izučavanja upućuju na to da ne postoji ljudska zajednica u kojoj u odgovarajućem istorijskom trenutku kult vatre nije zauzimao centralno mesto $u$ vezi sa naivnim shvatanjem sveta (Trojanović $1990,15-34)$.

$\mathrm{O}$ vatri je u okvirima istorije religije, folklora i narodne tradicije pisano izuzetno mnogo, što je očekivano s obzirom na predmet izučavanja - ona je jedan od elemenata čije je ovladavanje primitivnog čoveka uvelo u svet kulture (Loma 2008, 263-264). Mi ćemo se u narednim redovima na uporedne, $\mathrm{u}$ širem smislu, kulturološke podatke osvrtati onoliko koliko je to potrebno - imajući u vidu etnolingvistički predmet interesovanja, sa željom da se tekst ne pretvori $\mathrm{u}$ komentarisanje nauci poznatih podataka.

4.2. Sintagma živi oganj / živa vatra posvedočena je širom slovenskog prostora $u$ više različitih značenja..$^{15}$ Ovde se kratko predstavljaju samo značenja koja se mogu dovesti u vezu sa rekonstrukcijom motivacione baze frazeologizma bojati se (plašiti se, čuvati se, bežati od) koga/čega kao (od) <živog> ognja (<žive> vatre). ${ }^{16}$

Prvo, celi slovenski prostor zna za terminološku sintagmu živi oganj / živa vatra sa značenjem apotropejske vatre u okrilju etnologije bez obzira na to što je rečnici savremenih jezika često ne beleže. Ona se ne mora javiti u ovom obliku (mada je on filološki značajan) i posvedočena je u odgovarajućim varijantama, koje su motivisane kultom plodnosti i ulaskom u novi prolećno-letnji ciklus ili interferencijom sa hrišćanskim kulturnim kodom:

О. ж. - 'живой', 'новый' ,'молодой', 'божий, святой' (реже - 'дикий'): živ(о.-слав.), напр., с.-х. жива (ватра), болг. жив, болг. диал. ж' иф оган', пол, żywy (ogień) и т.д.; " nov- (рус. волж. новый огонь, болг. нов огън); *svęt(ю.-слав., гуцул., пол., бел.-полес., с.-рус.), напр., пол,- карпат. świenty ogień; bog- (пол., чеш., болг. нсврокоп.), напр., пол.-карпат. boży ogień',

\footnotetext{
${ }^{15}$ Sintagma označava ritualnu apotropejsku vatru, zatim otvoren, jak plamen, goruću vatru, vatru iz oružja, bolest, zatim strast, požudu, temperamentnog/strastvenog čoveka itd. (RJA, s. v. živ; PCA, s. v. жив; Караџић 1852, s. v. живи огањ; Keber 2015, živi ogenj).

${ }^{16}$ Objavljen rad posvećen rekonstrukciji istorijski primarnog značenja sintagme živi oganj / živa vatra (Begović 2018) predstavlja samo štokavsku građu. Ovde se donosi znatno proširena građa jer se data pojava sagledava na opšteslovenskom planu, u vezi sa motivacijom za nastanak razmatrane frazeološke slike.
} 
"mold- (болг. млад огън); div- (словен., с.-х., болг. родоп. див огън) (s. v. огонь живой, Славянские древности). ${ }^{17}$

Drugo, pored terminološkog značenja apotropejske vatre, sintagma živi oganj zabeležena je u dijalekatskim i frazeološkim rečnicima istočnoslovenskih jezika. Tako живы огни znači 'vatromet', живой огонь 'jaka vatra', живой уголь 'vatra, žar koji tinja' (Pavlović $2004,122,126)$. U velikom ruskom dijalekatskom rečniku takođe se navodi značenje otvorenog, jakog plamena pored značenja ritualne vatre (СНРГ, s. v. живой).

Sintagma živi oganj posvedočena je u poljskom i češkom jeziku sa značenjem otvorene, jake vatre, i to sa realizovanim primarnim značenjem imenice, kao i sa metaforički transponovanim imeničkim značenjem:

(1) „Podrapane kolana i łydki paliły, smagane żywym ogniem. Lecz cóż znaczy ból wobec myśli, że za chwilę odkryje“ (KJP, żywy ogień);

(2) „Oči mu vzplanuly neobyčejně živým ohněm. Just“ (PSJČ, s. v. oheň $).{ }^{18}$

Ovde treba istaći naročito vrednu potvrdu u gornjolužičkosrpskom korpusu. Naime, pored varijante analiziranog frazeologizma „bojeć so kaž wohnja něčeho“, u ovom jeziku zabeležen je i frazeologizam iste motivacije (prouzrokovač straha je vatra), ali sa ekspliciranim kongruentnim atributom živ - „kaž by žiwy woheń był za někim“, sa značenjem 'veoma brzo' (Ivčenko i dr. 2004). S obzirom na položaj i značaj lužičkosrpskog korpusa u opšteslovenskoj dijahronijskoj perspektivi, frazeološka slika o živom ognju kao stihiji koja prouzrokuje strah motivisana sintagmom žiwy woheń izuzetno je dragocena za dalju analizu.

\footnotetext{
${ }^{17}$ Deo literature o ritualnoj vatri imenovanoj sintagmom živi oganj / živa vatra može se naći u bibliografiji slovenskih radova o vatri, koju je sastavio D. Ajdačić (2008). Za upoznavanje sa pojmom žive vatre upućujemo na odrednice огонь живой і ватра (1) i (2) u referencama Славянские древности і Речник словенске митологије, zatim na podatke o živoj vatri u: Nodilo 1981 VI, 20-21, Trojanović 1990, Potebnía 1989, 530-552, Loma 1999a, Loma 1999b, Loma 2004, Loma 2005 (autor se opsežno bavio pojmom vatre i njenim različitim simboličkim manifestacijama ne samo $\mathrm{u}$ praslovenskoj nego i u staroj indoevropskoj religiji), zatim Belova i dr. 2008. Ovaj spisak mogao bi biti značajno širi, ali u navedenim radovima lako se dolazi do dalje literature o živoj vatri. Što se tiče nezaobilaznih udžbenika kulture, upućujemo na podatke o kultu vatre i živoj vatri u Elijade 1982, Frejzer 2003, Levi Stros 2008.

${ }^{18}$ Ukrajinski jezik zna za leksemu vatra, kao i poljski, češki i slovački jezik, koji znaju za leksemu vatra kao posledicu kontakta sa stočarskim kulturama na karpatskom pojasu (CУM, s. v. ватра; SJP, s. v. watra; PSJČ, s. v. vatra; SSJ, s. v. vatra).
} 
4.3. Značajne podatke o sintagmi živi oganj / živa vatra daje srpski (i hrvatski) korpus. Najstarije potvrde su sa značenjem otvorenog, jakog plamena (RJA, s. v. živ):

(1) „Put ove velike gore, ka ogań svoj živ meće sve vike k visine nebeskoj. D. Ranina 128“" (1563).

Mnoge primere upotrebe sintagme živi oganj (oganj živi) sa značenjem otvorenog plamena ili goruće, aktivne vatre nalazimo u srpskoj narodnoj epici:

(2) „На њега су до три обиљежа: | Вуча шапа и орлуја панџа, | Из зубах му живи огањ скаче [...] | Све у живи огањ запретала, | На огањ је сина нагорела“ (Змија младожења, варијанта из Црне Горе, Вук 1845 II, 63);

(3) „Плану Марко, као огањ живи“ (Сестра Леке капетана, Вук 1845 II, 239) itd.

Kolokacija živa vatra javlja se prvi put u 18. veku (RJA, s. v. vatra), a srpska epska poezija takođe zna za ovu sintagmu, sa značenjem otvorenog, jakog plamena ili goruće, aktivne vatre:

(4) „Ја украдох од змије кошуљу, | Па је турих на ту ватру живу“ (Змија младожења, Вук 1845 II, 59);

(5) „А кад Марко саслушао речи, | Крену Шарца, оде низ Косово, | Добра Шарца врло расрдио, | Из копита жива ватра сева, | Из ноздрва модар пламен лиже“ (Марко Краљевић укида свадбарину, Вук 1845 II, 421).

Pridev živ se u funkciji intenzifikatora i kvalifikatora imeničkog značenja $u$ nekim slučajevima nalazi u postpoziciji u odnosu na upravni član sintagme. Takvim postponovanjem kongruentnog atributa u savremenom jeziku postiže se dodatno isticanje, dok ovakva sintaksička pozicija atributa u narodnoj poeziji može odslikavati i relikt starijeg stanja $u$ istoriji jezika. Formulaični iskazi iz srpske narodne epike verovatno svedoče o fiksiranom starom redu reči 'imenica + pridev' jer se pridev $\mathrm{u}$ istoriji slovenskih jezika pomerao od postpozicije prema prepoziciji u odnosu na sintagmatski centar (Pavlović 2013, 92-93). Poredeći stanje u staroslovenskom jeziku sa starosrpskim stanjem u 12. i 13. veku, kao i sa staroruskim stanjem u spomenicima od 11. do 14. veka, autor na osnovu statističkih odnosa preponovanosti i postponovanosti prideva i zamenica zaključuje $\mathrm{da}$ „postponovanost kongruentne odredbe $u$ starosrpskom jeziku valja posmatrati prvenstveno kao razvojni relikt starijeg distributivnog stanja u procesu stabilizacije reda reči u okviru imenske fraze“ 
(Pavlović 2013, 93). Isto u vezi sa sintagmom bog živi ( $\rightarrow$ živi bog) $\mathrm{u}$ formulama zaklinjanja u starim srpskim poveljama primećuje i J. Grković-Mejdžor (2018, 17).

4.4. Rečnik slovenačkog književnog jezika beleži upotrebu prideva živ uz imenicu oganj i druge imenice što označavaju pojmove iz vatrenog domena: „ki še deluje: živo oglje še tleče / pazi, če je ogenj kje še živ" (SSKJ, s. v. živ). Potvrde ukazuju na realizaciju imenica u primarnom značenju i prideva živ u značenju 'aktivan, gorući'. Savremeni slovenački korpus ne beleži kolokaciju živi ogenj u značenju otvorenog, jakog plamena; to drugi primer pokazuje svojom sintaksom - ovde je živ deo imenskog predikata, a ne imeničke sintagme, čija bi sintaksička struktura uputila na ustaljenost i stabilnost značenja.

Međutim, $u$ jednom pastirskom obredu slovenački stočari idu oko vatre i izgovaraju formulu u kojoj razmatrana sintagma ostvaruje značenje otvorene vatre kao proždiruće nemani:

(1) „Živi ogenj, jari žerec, kožoderec, vse polizavec, vse požigavec, hom, hom, hom“ (Pajek 1884, 132; Štrekelj 1914, 402). ${ }^{19}$

4.5. O značaju srpske narodne epike za rekonstrukciju slovenske, pa i indoevropske duhovne kulture izlišno je govoriti (up. Loma 2002). Međutim, ovde valja istaći još nešto. Govoreći o arhaičnim slovenskim dijalekatskim zonama N. I. Tolstoj upućuje na H. Šuharta, koji je svojevremeno istakao važnost slovenačke oblasti kao čuvara „mnogobrojnih arhaičnih crta“" (Tolstoj 1995, 18).

Za nas su u tom smislu naročito važne paralele koje se mogu povući između semantike sintagme živi oganj / živa vatra u korpusu srpske narodne epike i slovenačke folklorne građe. Formule koje stočari izgovaraju dok igraju oko vatre i epske narodne formule mogu govoriti o nekadašnjoj predstavi ognjenog boga. S. Trojanović pretpostavlja da sintagmu živi oganj / živa vatra (i druge sintagme čiji su centar „vatreni“ pojmovi poput munje i groma) treba razumeti upravo s tim prvobitnim značenjem: „U vatri je stari svet uvek video neko živo biće, a tako i danas veruju svi primitivni narodi, a biće i ime naše žive vatre otuda da dolazi“ (Trojanović 1990, 30). U

\footnotetext{
${ }^{19}$ Poznato je da je kult vatre naročito dobro očuvan na jugu slovenske teritorije, posebno kod Srba i Hrvata (Nodilo 1981 VI: 20) i balkanskih stočara (Antonijević 1982). Najiscrpnije podatke o kultu vatre, a onda i živoj vatri i načinima njenog vađenja kod Srba daje S. Trojanović (1990), a podaci o kultu vatre uopšte kod Južnih Slovena mogu se naći u različitim etnološkim izvorima, uključujući i podatke iz bugarskog i slovenačkog folklora (npr. Karavelov 1868, 172; pomenuti Pajek 1884, 132; Štrekelj 1914, 402), čime se stiče šira slika o kultu vatre na južnoslovenskom prostoru.
} 
tom ključu treba razumeti i odgovarajuće kratke forme, kao okamenjene jezičke nanose u vezi sa naivnim mišljenjem: „Ovoga mi živog ognja!, „Živa ga munja spalila!“ (Trebješanin 1990, 409).

Navedeni podaci mogu se povezati sa semantikom apotropejske vatre, jer se u slovenskom kultu unutar šireg indoevropskog konteksta naslućuje upravo obožena vatrena stihija.

4.6. Živa vatra vadi se (izvija) u (pra)slovenskom kultu trenjem drveta o drvo, i to trenje dvaju drvaca ima simboliku seksualnog čina (Mršević-Radović 2014, 191). Ova simbolika ne očituje se samo u načinu vađenja žive vatre (o različitim postupcima kod Srba i simboličkoj interpretaciji v. Trojanović 1990, 74-129; kod drugih ie. naroda 129-137), već i u imenu drveta koja se koriste: kod Srba su to u nekim krajevima 'muškara' i 'ženskara' (Trojanović 1990, 74). Prema rečima A. Lome (1999a, 133), „simbolika seksualnog čina kao u ovim srpskim nazivima prisutna je kod drvaca čijim se trenjem izvodila žrtvena vatra u staroindijskoj religiji“, sa kojom slovenski kult vatre deli ubedljivo najviše sličnosti $u$ odnosu na druge ie. tradicije. Obred vađenja žive vatre trenjem drveta o drvo posvedočen je i kod drugih indoevropskih naroda. Kod Germana, Slovena i Helena potvrđena je i eksplicitna metafora falusa za muško drvo (Loma 1999a, 137). Seksualni čin sa sobom nosi simboliku stvaranja, pa vatra ima istaknutu ulogu u kultu plodnosti (čoveka, stoke, useva), ali treba imati na umu da je za stare Indoevropljane vatra kao centralni kosmogonijski element imala glavnu ulogu u sveopštoj obnovi života (Loma 1999a, 1999b) tako da su funkcije ovako dobijene svete vatre (trenjem drveta o drvo) bile mnogostruke. ${ }^{20}$

Za čitanje simbolike žive vatre vrlo je važna semantička interpretacija glagola koji imenuju radnju dobijanja ovakve vatre - ona se izvija ili vadi. A. Potebnja (Potebnía 1989, 536-541) to izvijanje interpretira u skladu sa jednim od načina vađenja žive vatre, koji podrazumeva okretanje (muškog) drveta u (ženskom) drvetu, što podražava stvaranje vatre na zemlji kao analog rađanja sunca na nebu. To je tačno, međutim, čini se da nije presudno to što se vatra izvija, već što se izvijanjem vadi. Ta vatra koja se dobija trenjem u

\footnotetext{
${ }^{20}$ U slovenskoj kulturi živa vatra je apotropej, štiti domaće životinje od bolesti, a njome se rado leče i ljudi (Trojanović 1990, 70, 72-73). U suštinskoj je vezi sa kultom ognjišta, tu predstavlja slovenski kontinuant pie. žrtvene vatre, koja ima zaštitničku moć. Ima centralno mesto u životnom ciklusu, od rođenja pa sve do smrti koristi se $\mathrm{u}$ različitim ritualima prelaza. Dakle, nije samo zaštitnica i vatra koja ima purifikacijsku moć, već je i važno sredstvo preobražaja, transmutacije (Elijade 1982, 116).
} 
drvetu je skrivena, latentna. ${ }^{21}$ Ovakvo viđenje vatre nalazi potpunu paralelu u staroindijskoj predstavi o tri vatre, koju čitamo u sledećim redovima Rigvede (X 45): „Agni se prvi put rodio od neba, drugi put od nas [ljudi] kao znalac bićâ (jātávedās-, naziv za žrtveni oganj), treći put u vodama“" (Loma 1999a, 15).22

Dobro poznate slovensko-indijske paralele ovde dozvoljavaju uslovno izjednačavanje slovenske žive vatre sa jednom od Agnijevih hipostaza - žrtvenom indijskom vatrom. ${ }^{23}$

Na kraju, o obogotvorenoj vatri kod Slovena ne govori samo kult žive vatre u pomenutom poređenju. Sloveni su sunce doživljavali kao nebeski oganj, a vatrenu stihiju kao živo biće (Словенска митологија, s. v. сунце, s. v. ватра). Afanasjev (Afanas'ev 1994 II, 5) podseća na to da su Sloveni Svarožića nazivali ognjem. Poznato je da se u slovenskoj mitologiji Perun identifikuje sa gromom, Dažbog sa suncem, a Svarožić upravo sa ognjem. Ne ulazeći u probleme rekonstrukcije stare slovenske religije, ukazujemo na to da se kao mogućnost u njenoj rekonstrukciji nameće henoteizam (Loma 2005), koji podrazumeva centralno božanstvo sa mnoštvom hipostaza $s$ obzirom na različite božanske funkcije, teritorijalnu raslojenost, osobenosti lokalnih kultova itd. (up. definiciju henoteizma u Müller 1878, 260). Ključni lik u henoteističkom konceptu slovenske religije mogao bi biti upravo Perun gromovnik, koji predstavlja „samo jedan od posebnih vidova projavljivanja iste stihije, nebeskog ognja“ (Loma 2005,15$){ }^{24}$

\footnotetext{
${ }^{21}$ Ne mora biti skrivena samo u drvetu nego i u kamenu (Ivanov i dr. 1974, 116).

${ }^{22}$ „U osnovi te Agnijeve trolikosti je kosmološka predstava o vatri koja kruži kroz vasionu: silazeći sa neba u vidu munje ona oplođava vodu svojim zametkom, koji putem zemnih sokova prodire u biljke iz kojih onda čovek izmamljuje ognjišnu ili žrtvenu vatru; na drugoj strani se taj zametak, nazvan „zlatnim embrionom“ (hiranyagarbha-), svakog jutra u moru nanovo rađa kao sunce. Dodamo li da se vatra dimom pretače $u$ vazduh, a vazduh prelazi $u$ vodu pretvaranjem magle $u$ rosu, oblaka u kišu, time se zatvara kružni tok elemenata u prirodi, u čijoj je osnovi oganj kao nepropadljivo načelo" (Loma 2005, 16).

${ }^{23}$ Staroindijski Agni i slovenski oganj dele pretpostavljenu etimologiju pie. obožene vatre (ЭССЯ 32, s. v. *ognb).

${ }^{24}$ Obogotvoreni nebeski oganj, tj. aktivno nebo u čijem se domenu pojavljuje sunce, grom, munja, spada u civilizacijski arhetip. Na uporednom indoevropskom planu pie. bog neba *Dyeus dovodi se u vezu sa munjom (Loma 2005, 14; Mallory i dr. 2006, 408-409).
} 


\section{K. Begović \\ Bojati se (plašiti se, čuvati se, bežati od ...}

4.7. Rekonstrukcija sintagme živi oganj / živa vatra sa terminološkim značenjem na praslovenskom nivou je poznata - *živy(jb) ognb / "živa(ja) vatra (Ivanov i dr. 1965, 144). ${ }^{25}$

Međutim, ova je sintagma polisemična i izgleda da je terminološko značenje apotropejske vatre već metonimijski sekundarno i da je potisnulo nekadašnje značenje sintagme koje je sačuvalo naivnu predstavu obožene vatre, fiksirano u jeziku srpske narodne poezije i govornim formulama u slovenačkom kultu stočara.

Pretpostavka da je istorijski primarno značenje analizirane sintagme doslovno $\mathrm{u}$ široj etno(mito)loškoj literaturi nije nova (Kuhn 1859, 223-228; Trojanović 1990, 30). No, ovu hipotezu ubedljivo potkrepljuje i jezički materijal. Sva komentarisana značenja sintagmi živi oganj / živa vatra na srpskom (i hrvatskom) i slovenačkom prostoru, kao i na širem slovenskom prostoru (terminološko značenje apotropejske vatre, značenje jakog, otvorenog plamena, kao i značenje goruće vatre), mogu se izvesti iz rekonstruisanog istorijski primarnog značenja sintagme 'ognjeni bog'.

Sekundarno značenje žrtvene i apotropejske vatre (upravo vatre koja je imala ključnu ulogu u različitim domenima pod pokroviteljstvom boga vatre) nastalo je specijalizacijom, sužavanjem primarnog značenja 'obožena, živa vatra'. ${ }^{26}$

Pridev živ se na zapadnojužnoslovenskom (i na širem slovenskom) prostoru koristi u značenju 'aktivan' uz imenice vatra i oganj. U ovom značenju koristi se i uz druge imenice koje označavaju pojmove iz „vatrenog“ domena (žar, žiška, žeravica itd.). Značenje 'aktivan' iz savremene perspektive je sekundarno, metaforički motivisano, i u srpskim izvorima javlja se od 15 . veka (za srpski (i hrvatski) i slovenački materijal v. RJA, s. v. živ; PCA, s. v. жив; SSKJ, s. v. živ).

Međutim, istorijska analiza polisemantičke strukture prideva živ pokazuje da se njegovo rano pie. primarno značenje verovatno svodilo na semantički primitiv 'živ', koji bi se mogao definisati kao 'sa-

\footnotetext{
${ }^{25}$ Autori rekonstruišu na psl. planu obe sintagme, a iz prikupljenih podataka proističe da se postanak sintagme sa leksemom vatra sužava na period 2-5. vek n. e. Oganj je praslovenska i sveslovenska leksema nasleđena iz pie. jezika (ЕСCЯ, s. v. *ognb; Mallory i dr. 2006, 122-123). Leksema vatra je iranskog porekla - ätar-/äAro- (Loma 2005, 21-22; Mallory i dr. 2006, 123), i pretpostavlja se da je u južnoslovenski prostor ušla kao psl. pozajmica iz zapadnoiranskih dijalekata (Trojanović 1990, 357-372). A. Loma $(2005,21)$ precizira Trojanovićevu hipotezu pretpostavkom da je ir. vatra na delu slovenskog prostora posledica davnašnjeg uticaja Skita i Sarmata na nekadašnji jugoistok praslovenske teritorije.

26 Specijalizacija i generalizacija (progresivno sužavanje i širenje značenja) predstavljaju podvrste metonimijskog mehanizma semantičke transpozicije. Baš zato što se zasnivaju na metonimijskom prenosu (Halas 2017, 17), u srbističkoj literaturi se najčešće ne pominju kao posebni mehanizmi.
} 
mopokretan, aktivan' (Wierzbicka 1996, 124-126; Grković-Mejdžor 2018, 15-16). U tom svetlu vrlo je moguće da sintagme živi oganj / živa vatra u značenju 'aktivna vatra (ona koja se širi, pomera itd.)', živa voda u značenju 'tekuća voda', kao i živi bog kao aktivna sila koja nadzire zakletvu i njeno sprovođenje (up. Grković-Mejdžor 2018), predstavljaju relikte ranog pie. značenja prideva (Begović 2019, 70-155).

Čini se da je frazeološka slika u kojoj je značenje 'mnogo se plašiti' eksplicirano strahom od vatre motivisana sintagmom živi oganj / živa vatra u značenju obožene vatrene stihije, i da u tom smislu naročitu starinu u odnosu na ostale slovenske jezike pokazuju srpski i slovenački, kao i gornjolužičkosrpski materijal.

\section{Osobenost srpskog i slovenačkog plana: pridev živ kao intenzifikator frazeološkog značenja}

Potvrde sintagme živi oganj / živa vatra koja se realizuje u značenju otvorenog, jakog plamena nalazimo na širem slovenskom prostoru - u zapadnojužnoslovenskom arealu (sa makedonskim jezikom na razmeđi južnoslovenskih glosa), u delu zapadnoslovenskih jezikâ - poljskom i češkom, zatim u ruskom jeziku itd. U nekim jezicima ovo značenje sintagme je zastarelo, u nekima nije. Značenje je potvrđeno i u dijalekatskim korpusima, a najstarija potvrda o ovom značenju sintagme jeste iz polovine 16 . veka (RJA, s. v. živ). Disperzivna slika aktuelnosti i arhaičnosti značenja sintagme na širem slovenskom prostoru, zajedno sa dijalekatskim i istorijskim potvrdama, govori ili o potencijalnom psl. nasleđu ili o davnom komplementarnom istorijskom semantičkom pomaku u pojedinačnim slovenskim jezicima.

Sintagme živi oganj / živa vatra u motivacionu bazu frazeologizma bojati se (plašiti se, čuvati se, bežati od) koga/čega kao (od) <živog> ognja (<žive> vatre) u srpskom (i hrvatskom) i slovenačkom jeziku ulaze sa značenjem 'otvoreni, jak plamen, vatra u svojoj suštini'. To znači da se pridev živ već u nefrazeološkoj bazi ostvaruje u semantičkoj poziciji intenzifikatora i kvalifikatora imeničkog značenja. ${ }^{27} \mathrm{U}$ semantičkoj transpoziciji tokom frazeologizacije pridev se pomera

\footnotetext{
${ }^{27}$ Ovaj pridev inače odlikuje sklonost ka desemantizaciji (delimičnoj ili potpunoj) i različitim kontekstualnim modulacijama zbog same prirode njegove semantike, koja je dosta široka i apstraktna u različitim svojim realizacijama. To pridevu omogućava da se realizuje kao intenzifikator i kvalifikator leksičkog značenja imenice uz koju stoji (up. primere živa sila, živa želja, živa zgoda itd.), kao intenzifikator apsolutnog upućivanja (sve živo, ništa živo), i kao intenzifikator i kvalifikator frazeološkog značenja (živa enciklopedija, živa legenda, živa dosada itd.). Više v. u Begović 2019.
} 
od intenzifikatora i kvalifikatora leksičkog značenja izraženog imenicama oganj/vatra do intenzifikatora frazeološkog značenja.

Međutim, opisana semantička realizacija sintagmi živi oganj / živa vatra može se interpretirati kao relikt predstave o oboženoj vatri.

H. Valter i V. Mokijenko, razmatrajući metodološke izazove $u$ praslovenskoj leksičkoj i frazeološkoj rekonstrukciji, ističu da naročitu pažnju zahtevaju leksički spojevi (ne nužno frazeologizmi u užem smislu) koji su kroz istoriju pokazali sposobnost semantičke kondenzacije do leksičkog značenja, tj. univerbizacije - „die semantische Kondensation (resp. die Univerbierung) “ (Walter i dr. 2018, 332).

S jedne strane, pozicija prideva intenzifikatora frazeološkog značenja u srpskom i slovenačkom korpusu jeste posledica specifične semantike prideva. S druge strane, s obzirom na izložene etnološke, mitološke i kulturološke podatke, kao i s obzirom na jezičku rekonstrukciju odgovarajućih značenja sintagmi živi oganj / živa vatra, treba ostaviti mogućnost univerbizaciji rematskog dela frazeološke jedinice $u$ onim slovenskim jezicima $u$ kojima se na mestu sintagme nalazi samo leksema oganj: živi oganj $\rightarrow$ oganj. U ovakvoj interpretaciji činilaca frazeološkog značenja srpski i slovenački jezik na obodu slovenske teritorije čuvali bi arhaične crte frazeološke strukture. Na isti način može se interpretirati stanje posvedočeno u gornjolužičkosrpskom korpusu: frazeologizam „bojeć so kaž wohnja něčeho" svedočio bi o inovaciji u frazeološkoj strukturi, zajedno sa većim delom slovenskog prostora; međutim, frazeologizam iste motivacije „kaž by žiwy woheń był za někim“ svedočio bi o arhaičnoj crti frazeološke strukture sa ekspliciranim kongruentnim atributom živ i, s tim u vezi, o nekadašnjoj predstavi obožene vatrene stihije.

\section{Pretpostavljena starina frazeologizma}

6.1. N. I. Tolstoj $(1995,82)$, govoreći o rekonstrukciji frazeologizama na psl. planu, ističe da je, za razliku od leksičke rekonstrukcije, poželjno da frazeologizam ne bude posvedočen u svim slovenskim jezicima, već samo u perifernim dijalekatskim zonama (što potencijalno svedoči o starini frazeološke jedinice). Ako je frazeologizam potvrđen širom slovenskog prostora, verovatno je da ćemo ga naći i u korpusu zapadnoindoevropskih jezika, tj. da neće biti autohtoni slovenski, već kalkiran.

Međutim, čini se da je moguće da spojevi reči budu posvedočeni na velikom delu slovenskog govornog prostora, a da to ne znači nužno inovaciju u razvoju pojedinačnih slovenskih jezika ili kalkira- 
nje; očekivano je da spojevi reči koji odražavaju suštinske kulturne koncepte budu istorijski stabilni (Walter i dr. 2018). ${ }^{28}$

Prema H. Valteru i V. M. Mokijenku, na postojanost psl. frazeološkog fonda nesporno upućuje slovenski jezički materijal, i to jezički materijal posvedočen na opšteslovenskom prostoru. Kao jedan od primera psl. frazeologizma navode držati jezik za zubima, koji je posvedočen na širem slovenskom prostoru, a u poljskim spomenicima već od 15. veka (Walter i dr. 2018, 331-332). Autori naglašavaju nerazjašnjen status psl. frazeološkog fonda $u$ istraživanjima slovenskih jezika i ukazuju na veliku diskrepanciju u sigurnosti leksičke psl. rekonstrukcije u odnosu na frazeološku: „Die Darstellung der slawischen Ursprache stößt jedoch auf ein Paradoxon. Wenn die urslawische Lexik als bewiesen gelten kann, dann bleibt jedoch der Status der urslawischen Phraseologie unbestimmt ${ }^{\text {"29 }}$ (Walter i dr. 2018, 332).

6.2. Iz naše perspektive, posvedočenost frazeološke jedinice $u$ opšteslovenskom korpusu može govoriti o: (1) autentičnom psl. nasleđu, (2) širem pie. nasleđu, (3) pozajmljivanju ili o (4) istovetnom razvoju pojedinačnih slovenskih jezika.

Tako sintagma živi oganj / živa vatra sa očuvanim terminološkim značenjem ritualne vatre širom slovenskog prostora (u različitim varijantnim oblicima) predstavlja (1) psl. nasleđe, koje se, razmatra kao (2) inovacija proistekla iz šireg pie. semiotičkog koda.

S druge strane, formule iz srpske narodne epike, različite govorne formule $u$ vezi sa 'vatrenim pojmovima' poput munje, groma, kao i jezički podaci u vezi sa kultom slovenačkih stočara, gde se pridev danas realizuje kao intenzifikator imeničkog značenja, a zatim i potvrda iz gornjolužičkosrpskog korpusa, verovatno govore o reliktu arhaičnog psl. značenja ognjenog boga, koje je ostalo sačuvano $u$ perifernoj slovenskoj dijalekatskoj zoni.

6.3. S obzirom na iznesene podatke $\mathrm{u}$ analizi frazeologizma $b o-$ jati se (plašiti se, čuvati se, bežati od) koga/čega kao (od) <živog> ognja (<žive> vatre), kao mogućnosti istorijskog razvoja izdvajaju se dve mogućnosti: (1) autentično psl. nasleđe i (4) istovetni razvoj pojedinačnih slovenskih jezika.

\footnotetext{
${ }^{28}$ To ne isključuje činjenicu da se psl. frazeologizam (u širem smislu) ne može arhaizirati i očuvati samo u perifernim zonama slovenskog prostora (up. analizu sintagme živa voda u značenju vode koja izvire i tekuće vode u Begović 2018).

29 „Međutim, prezentacija praslovenskog jezika nailazi na paradoks. Koliko se praslovenska leksika smatra dokazanom, toliko status praslovenske frazeologije ostaje nerazjašnjen“ (prevela K. B.).
} 
6.3.1. Pretpostavku da frazeologizam predstavlja kulturnu i jezičku slovensku univerzaliju nastalu $u$ istorijskom periodu pojedinačnog razvoja slovenskih jezika potvrđuju jezička fakta. U ovom slučaju motivacija za nastanak frazeološke slike tumačila bi se strahom od vatrene stihije uopšte, $u$ kojoj je moguće videti i relikt kulta obožene vatre i naivnog shvatanja sveta naših predaka.

6.3.2. S druge strane, etnolingvistički materijal upućuje na veliku starinu jedinica živi oganj / živa vatra u značenju apotropejske vatre i rekonstruisanom značenju obožene stihije. S obzirom na to, kao i s obzirom na univerzalni strah od vatre i činjenicu da su suštinski koncepti jednog etnokulturnog koda uglavnom istorijski stabilni, možda treba ostaviti mogućnost pretpostavci da su naši preci u poznom psl. periodu veliki strah izražavali najvećim izazivačem straha u naivnom shvatanju sveta. Analizirani frazeologizam širom slovenskog prostora svedočio bi o takvom shvatanju sveta, sa očuvanim arhaičnim crtama u srpskom i slovenačkom jeziku, zajedno sa srodnom potvrdom iz gornjolužičkosrpskog jezika.

Ovakva hipoteza zahteva poseban osvrt na sintaksičku strukturu analizirane jedinice. Frazeologizam bojati se (plašiti se, čuvati se, bežati od) koga/čega kao (od) <živog> ognja (<žive> vatre) podrazumeva elidiran predikat $\mathrm{u}$ rematskom delu frazeološke strukture eksplikacija predikacije ovde nije potrebna - bojati se čega kako (se bojati) živog ognja. Stanje/radnja iskazana predikatom poredi se sa istim stanjem/radnjom u prototipičnim uslovima u kojima se takvo stanje/radnja izražava u velikoj meri. Govoreći o poredbenim rečenicama u staroj srpskoj poslovno-pravnoj pismenosti, S. Pavlović ističe da „situacije u kojima su korelativne predikacije predstavljene identičnim glagolima omogućuju redukciju poredbene rečenice i njeno svođenje na nominalnu poredbenu konstrukciju“ (Pavlović 2009, 211).

Poredbene strukture sa veznikom *jako posvedočene su u staroslovenskom jeziku (CC, s. v. rako). S. Pavlović izveštava da su hipotaksički poredbeni odnosi izraženi veznicima *jako ili *kako u korpusu pojedinačnih neredakcijskih slovenskih pismenosti (starosrpskog, staroruskog, staropoljskog, staročeškog jezika) zabeleženi već u najstarijim spomenicima (Pavlović 2009, 227). Posvedočenost u korpusu narodnih jezika je potencijalno važna. Ona bi mogla upućivati u doistorijskom periodu razvoja jezika na raniji razvoj logičkog mišljenja poredbenog odnosa, koje se dalje semantički diferenciralo i razvijalo sa potporom u pisanom jeziku. 
Međutim, istoričari sintakse uglavnom se slažu u tome da hipotaksa ima uporište u pisanom jeziku i da je vrlo teško govoriti o eventualnim hipotaksičkim modelima praslovenskog jezika (Pavlović 2013, 295). Pritom, naročitu pažnju treba obratiti na kalkiranje, pogotovu kada se uzme u obzir da je svako savladavanje pismenosti podrazumevalo crkvenoslovenski kod, a da je staroslovenska hipotaksa, koju redakcijski sistemi nasleđuju, oblikovana prema grčkom modelu.

No, bez obzira na navedeno, govoreći o rekonstrukciji govorne sintakse uopšte, I. Grickat upozorava na sledeće: „U ranim epohama indoevropskih jezika hipotaksa verovatno zaista nije bila bogata, ali su neki njeni uopšteni modeli svakako već bili utvrđeni. To se saznaje na prvom mestu iz relativnih pridevskih, priloških, zameničkih i vezničkih izvedenica sa prvobitno pronominalnim korenima, čije principske međujezičke sličnosti govore o velikoj starini - kod većine jezika još pretpismenoj. Govorna hipotaksa, prema tome, mogla je biti primitivna, ali joj pomoć literarne hipotakse nije bila potrebna" (Grickat 2004, 66).

Pritom, poreklo poredbenih rečenica sa veznikom *jako treba tražiti u povezivanju dveju nezavisnih rečeničnih struktura u kojima je upravo primarno deiktičko *jako služilo kao naslon koji je omogućio složenu rečeničnu strukturu (Grickat 2004, 79; Pavlović 2009, $227-228$ ). Poreklo poredbenih rečenica sa veznikom *kako verovatno treba tražiti u prvobitnom pitanju uvedenom upitnim prilogom, koje je s vremenom gubilo svoju autonomnu rečeničnu intonaciju i dobijalo status zavisnog člana rečenične strukture (Pavlović 2009, 219). S tim u vezi, u motivacionoj bazi frazeologizma treba rekonstruisati veznik *jako. Veznik *kako na tom mestu u različitim slovenskim jezicima rezultat je širenja veznika $k$-tipa na račun veznika i-tipa. ${ }^{30}$ Takav je slučaj sa srpskim jezikom, u čijim je dijalektima početni oblik veznika kako kroz istoriju pretrpeo različite glasovne promene (RJA, s. v. kao). Slovenački jezik zna za varijantu kakor sa partikularnim $-r<r e<* z ̌ e$.

S obzirom na iznete podatke, frazeologizam bi se uslovno mogao rekonstruisati u poznom psl. jeziku kao * bojati sę (...) kogo/česogo jako [bojati sę] živajego ogn'a, s tim da se podrazumeva mogućnost leksičkog variranja glagola u tematskom delu frazeologizma. Pri-

30 o prostiranju veznika *jako i *kako širom slovenskog prostora i njihovoj diferenciranoj prirodi $i$-tipa (anaforskoj, prvobitno demonstrativnoj) i $k$-tipa (upitnoj, pa takođe i neodređenoj) up. Grickat 2004, 67-74, Pavlović 2009, 210-229, gde v. drugu literaturu o pitanju. 
dev živ bi u ovakvom kontekstu morao biti realizovan u složenom pridevskom obliku jer se odnosi na poznati pojam.

Opisanoj frazeološkoj strukturi svakako treba tražiti dublje poreklo u parataksičkom odnosu. Ono što se može zaključiti jeste da je nefrazeološki bazni oblik podlegao frazeologizaciji onda kada se parataksička struktura u jezičkom osećanju počela doživljavati kao hipotaksička, jer je kao takva upućivala na neraskidivu sintaksičku vezu unutar formirane složene rečenice.

\section{Zaključna razmatranja}

Predmet ovog rada jeste dijahronijska analiza poredbenog komponentnog frazeologizma bojati se (plašiti se, čuvati se, bežati od) koga/čega kao (od) <živog> ognja (<žive> vatre) u slovenskim jezicima, sa posebnim osvrtom na srpski i slovenački plan. Teorijsko-metodološki temelj analize jeste strukturno-semantički, u okvirima istorijske frazeologije, i širi etnolingvistički, s obzirom na etnokulturni i mitološki podtekst u kom se analizirana jezička jedinica posmatra.

Građa je ekscerpirana iz različitih leksikografskih izvora, a u radu se ističu različiti izazovi u vezi sa stvaranjem reprezentativnog uzorka istorijskog frazeološkog korpusa.

Pretpostavlja se da je frazeologizam potekao u narodnom izrazu slovenskih jezika s obzirom na (1) njegovu posvedočenost širom slovenskog prostora, (2) odsustvo u zapadnoindoevropskim jezicima, (3) pripadnost frazeologizma bugarskom dijalekatskom korpusu, (4) potvrdu iz srpskog istorijskog korpusa. Ova hipoteza potkrepljuje se odgovarajućim etnokulturnim, mitološkim i etimološkim podacima u vezi sa sintagmama živi oganj / živa vatra, koje se razmatraju kao motivacija za analizirani frazeologizam.

Predlaže se motivaciona baza koja podleže frazeologizaciji, kao i sam tok kojim je frazeologizacija išla, strukturno i semantički.

Razmatraju se specifičnosti srpskog i slovenačkog korpusa, u kojem se pridev živ realizuje u rematskom delu frazeologizma kao atribut uz imenice oganj/vatra. Zaključuje se da pridev živ u frazeologizaciju ulazi kao intenzifikator i kvalifikator leksičkog značenja imenica, a u frazeološkoj transpoziciji dobija ulogu intenzifikatora frazeološkog značenja. Pretpostavlja se da se u sintagmama živi oganj / živa vatra krije i značenje obožene stihije iz kulta vatre, čime srpsko-slovenačke paralele zajedno sa potvrdom iz gornjolužičkosrpskog korpusa istupaju kao nosioci arhaičnih crta opšteslovenskog prostora. U skladu sa tim, ostavlja se mogućnost univerbizaciji 
sintagmi živi oganj $\rightarrow$ oganj / živa vatra $\rightarrow$ vatra u ostalim slovenskim jezicima.

Zaključuje se da je frazeologizam verovatno nasleđen iz poznog praslovenskog jezika u pretpostavljenom obliku * bojati sę (...) kogo/ česogo jako [bojati sę] živajego ogn'a, s tim da se ostavlja mogućnost i pretpostavci da predstavlja rezultat komplementarnog razvoja širom slovenskog prostora.

Leksikografski izvori

Бирих, Александр К., Валерий М. Мокиенко, Людмила И. Степанова. 2005. Русская фразеология. Историко-этимологический словарь. Москва: Астрель АСТ.

Караџић, Вук С. 1818. Српски рјечник истолкован њемачким и латинским ријечма. У Бечу : у штампарији Јерменскога манастира.

Караџић, Вук С. 1852. Српски рјечник истумачен њемачкијем и латинскијем ријечима. У Бечу : у штампарији Јерменскога манастира.

РМС. Речник српскохрватскога књижевног језика, I-VI. 1967-1976. Нови Сад : Матица српска.

РСА. Речник српскохрватског књижевног и народног језика. 1959-. Београд : САНУ.

РСЈ. Речник српскога језика. 2007. Нови Сад : Матица српска.

СРЯ. Словарь русского языка XI-XVII вв. 1975-. Москва : «Наука».

СРНГ. Словарь русских народных говоров. 1972. Ленинград : Издательство «Наука».

СС. Словарь старослявянского языка (по рукописям X-ХІ веков). 1994. Москва : «Русский язык».

ЭССЯ. Этимологический словарь славянских языков. Праславянский лексический фонд. 1974-. Москва : Наука.

Ivčenko Anatolij, Sonja Wölke. 2004. Hornjoserbski frazeologiski słownik. Budyšin/Bautzen : Ludowe nakładnistwo Domowina.

Matešić, Josip. 1982. Frazeološki rječnik hrvatskoga ili srpskog jezika. Zagreb : Školska knjiga.

RJA. Rečnik hrvatskoga ili srpskoga jezika, I-XXIII. 1880-1976. Zagreb : JAZU. 
Digitalni leksikografski i korpusni izvori

БТС. Большой толковый словарь русского языка (гл. ред. С. А. Кузнецов). 2014. Санкт Петербург : Норинт, 1998 (первое издание), публикуется в авторской редакции 2014 года. Доступан на http://www.gramota.ru.

ДРМЈ. Дигитален речник на македонскиот јазик, верзија: 1.2.002-. 1997-2019. Доступан на http://www.makedonski.info.

РБЕ. Речник на българския език. 2001-. София : Академично издателство „Проф. Марин Дринов“ / ЕТ „Емас“. Доступан на http://ibl.bas.bg.

Скарник. Тлумачальны слоўнік беларускай мовы, Скарнік - тлумачальны слоўнік на аснове пяцітомніка 1977-1984 гг. (акадэмічнае выданне пад рэдакцыяй К. Крапівы). Доступан на http://www. skarnik.by.

СУМ. Словник української мови, Академічний тлумачний словник, в 11 т. 1970-1980. Київ : Наукова думка. Доступан на http://sum.in.ua.

Keber, Janez. 2015. Slovar slovenskih frazemov. Ljubljana : Inštitut za slovenski jezik Frana Ramovša ZRC SAZU, elektronska objava, spletna izdaja na http://fran.si.

KJP. Korpus Języka Polskiego, 1997-2019. Dostupan na http://sjp.pwn.pl.

PSJČ. Př́ruční slovník jazyka českého, I-VI. 1935-1957. Praha : Státní nakladatelství / Školní nakladatelství - SPN. Dostupan na http:// www.ujc.cas.cz.

SJPD. Słownik języka polskiego (red. W. Doroszewski). 1958-1969. Warszawa : Wydawnictwo Wiedza Powszechna / Państwowe Wydawnictwo Naukowe. Dostupan na http://sjp.pwn.pl.

SSJ. Slovník slovenského jazyka I-VI. 1959-1968. Bratislava : Vydavatel'stvo SAV. Dostupan na http://slovniky.juls.savba.sk.

SSKJ. Slovar slovenskega knjižnega jezika, druga, dopolnjena in deloma prenovljena izdaja. 2014. Ljubljana : Inštitut za slovenski jezik Frana Ramovša ZRC SAZU, elektronska objava, spletna izdaja na http:// fran.si.

Ostali izvori

Библија, Свето писмо Старога и Новога завјета (прев. Ђуро Даничић и Вук Стефановић Караџић). 2017. Београд : Библијско друштво Србије.

Каравелов, Љубен. 1868. „Бугари старог кова“. Вила 8: 169-179.

Караџић, Вук С. 1841. Српске народне пјесме, књига прва, у којој су различне женске пјесме. У Бечу : у штампарији Јерменскога манастира. 
Караџић, Вук С. 1845. Српске народне пјесме, књига друга, у којој су пјесме јуначке најстарије. У Бечу : у штампарији Јерменскога манастира.

Словенска митологија, енциклопедијски речник. 2001. Ред. Светлана Толстој, Љубинко Раденковић. Београд : Zepter Book World.

Славянские древности, Этнолингвистический словарь. 1995-2012. Ред. Т. А. Агапкина, Л. Н. Виноградова, В. Я. Петрухин, С. М. Толстая. Москва: «Международные отношения».

Pajek, Josip. 1884. Črtice iz duševnog žitka štajerskih Slovencev. Ljubljana : Matica slovenska.

Štrekelj, Karel. 1914. Slovenske narodne pesmi 1. Ljubljana : Slovenska matica.

\section{Literatura}

Afanas'ev 1994. - Афанасьев, Александр Н. 1994. Поэтические воззрения славян на природу, в 3 т. (репринт 1865 года). Москва : Индрик [Afanas'ev, Aleksandr N. 1994. Poèticheskie vozzreniia slavian na prirodu, v 3 t. (reprint 1865 goda). Moskva : Indrik].

Ajdačić 2008. - Ајдачић, Дејан. 2008. „Библиографија о ватри у народној култури Словена“. Кодови словенских култура 10 - Ватра: 300-308 [Ajdačić, Dejan. 2008. „Bibliografija o vatri u narodnoj kulturi Slovena“. Kodovi slovenskih kultura 10 - Vatra: 300-308].

Antonijević 1982. - Антонијевић, Драгослав. 1982. Обреди и обичаји балканиских сточара. Београд : Балканолошки институт САНУ [Antonijević, Dragoslav. 1982. Obredi i običaji balkaniskih stočara. Beograd : Balkanološki institut SANU].

Barčot 2017. - Barčot, Branka. 2017. Lingvokulturologija i zoonimska frazeologija. Zagreb : Hrvatska sveučilišna naklada.

Begović 2018. - Begović, Katarina. 2018. „Etimološki primarno značenje sintagmi živi oganj / živa vatra na srpsko-hrvatskom jezičkom području“. U Beiträge zum 21. Arbeitstreffen der Europäischen Slavistischen Linguistik (Polyslav), Band 21, 8-17. Wiesbaden : Harrassowitz Verlag.

Begović 2018. - Беговић, Катарина. 2018. „Жива вода као божанска хипостаза - етимолошки примарно значење синтагме жива вода“. Кюижевност и језик 65, 3-4: 361-375 [Begović, Katarina. 2018. „Živa voda kao božanska hipostaza - etimološki primarno značenje sintagme živa voda“. Književnost i jezik 65, 3-4: 361-375]

Begović 2019. - Беговић, Катарина. 2019. Фразеологизми са компонентом жив на српском и јужнословенском говорном простору: дијахронијски и синхронијски аспект. Докторска дисертација. Универзитет у Београду - Филолошки факултет [Begović, Katarina. 2019. Frazeologizmi sa komponentom živ na srpskom $i$ 
južnoslovenskom govornom prostoru: dijahronijski i sinhronijski aspekt. Doktorska disertacija. Univerzitet u Beogradu - Filološki fakultet].

Belova \& Petrukhin 2008. - Белова, Ольга и Владимир Петрухин. 2008. „«Живой огонь»: мифология и этнография“. Кодови словенских култура 10 - Ватра: 5-12. [Belova, Ol'ga i Vladimir Petrukhin. 2008. „«Zhivoĩ ogon'»: mifologina i ètnografiîa“. Kodovi slovenskikh kultura 10 - Vatra: 5-12].

Dragićević 2010. - Драгићевић, Рајна. 2010. Вербалне асоцијације кроз српски језик и културу. Београд : Друштво за српски језик и књижевност Србије [Dragićević, Rajna. 2010. Verbalne asocijacije kroz srpski jezik $i$ kulturu. Beograd : Društvo za srpski jezik i književnost Srbije].

Elijade 1982. - Elijade, Mirča. 1982. Kovači i alkemičari. Zagreb : Grafički zavod Hrvatske.

Frejzer 2003. - Frejzer, Džejms Dž. 2003. Zlatna grana, Proučavanje magije $i$ religije. Beograd : Ivanišević.

Gabrić-Bagarić 2013. - Gabrić-Bagarić, Darija. 2013. „Fra Matije Divkovića Nauk krstjanski (1611.)“. U Nauk krstjanski za narod slovinski ; Sto čudesa aliti znamen'ja blažene i slavne Bogorodice, Divice Marije, Matija Divković, ur. M. Karamatić, 7-80. Sarajevo : Kulturnopovijesni institut Bosne Srebrene.

Grickat 2004. - Грицкат, Ирена. 2004. Студије из историје српскохрватског језика. Београд : Завод за издавање уџбеника [Grickat, Irena. 2004. Studije iz istorije srpskohrvatskog jezika. Beograd : Zavod za izdavanje udžbenika].

Grković-Mejdžor 2018. - Грковић-Мејџор, Јасмина. 2018. „Архаични формулаични искази у повељама средњовековне Босне и Хума". У Српско писано насљеђе и историја средњовјековне Босне и Хума, уредник Зорица Никитовић, 11-24. Бања Лука : Филолошки факултет Универзитета у Бањој Луци / Источно Сарајево : Филозофски факултет Универзитета у Бањој Луци - Филозофски факултет Универзитета у Источном Сарајеву [Grković-Mejdžor, Jasmina. 2018. „Arhaični formulaični iskazi u poveljama srednjovekovne Bosne i Huma". U Srpsko pisano nasljeđe i istorija srednjovjekovne Bosne i Huma, urednik Zorica Nikitović, 11-24. Banja Luka : Filološki fakultet Univerziteta u Banjoj Luci / Istočno Sarajevo : Filozofski fakultet Univerziteta u Banjoj Luci Filozofski fakultet Univerziteta u Istočnom Sarajevu].

Halas Popović 2017. - Халас Поповић, Ана. 2017. Увод у лексичку полисемију. Нови Сад : Филозофски факултет [Halas Popović, Ana. 2017. Uvod u leksičku polisemiju. Novi Sad : Filozofski fakultet].

Ivanov \& Toporov. 1965. - Иванов, Вячеслав В. и Владимир Н. Топоров. 1965. Славянские языковые моделирующие семиотические системы (древний период). Москва : Наука [Ivanov, Vîacheslav V. i Vladimir N. Toporov. 1965. Slaviānskie íazykovye modeliruiushchie semioticheskie sistemy (drevni⿱̌ period). Moskva : Nauka]. 
Ivanov \& Toporov. 1974. - Иванов, Вячеслав В. и Владимир Н. Топоров. 1974. Исследования в области славянских древностей. Москва : Наука [Ivanov, Vîacheslav V. i Vladimir N. Toporov. 1974. Issledovaniia $v$ oblasti slaviânskikh drevnostě̆. Moskva : Nauka].

Kuhn 1859. - Kuhn, Adalbert. 1859. Herabkunft des Feuers und des Göttertranks. Berlin : Ferd. Dümmler's Verlagsbuchhandlung.

Larin 1977. - Ларин, Борис, А. 1977. История русского языка и общее языкознание. Москва : Просвещение [Larin, Boris, А. 1977. Istoriia russkogo iâzyka i obshchee iâzykoznanie. Moskva : Prosveshchenie].

Levi Stros 2008. - Levi Stros, Klod. 2008. Presno i pečeno. Novi Sad : Kiša.

Loma 1995. Лома, Александар. 1995. „Даље од речи: реконструкција прајезичких лексемских спојева као перспектива словенске и индоевропске етимологије“. Јужнословенски филолог 51: 31-58 [Loma, Aleksandar. 1995. „Dalje od reči: rekonstrukcija prajezičkih leksemskih spojeva kao perspektiva slovenske i indoevropske etimologije“. Južnoslovenski filolog 51: 31-58].

Loma 1999a. - Лома, Александар. 1999а. „Петлић, палидрвце или оплодитељ“. Кодови словенских култура 4 - Делови тела: 131-143 [Loma, Aleksandar. 1999a. „Petlić, palidrvce ili oploditelj“. Kodovi slovenskih kultura 4 - Delovi tela: 131-143].

Loma 1999b. - Loma, Aleksandar. 1999b. Mitski koreni filozofije. Lucida intervalla 8-9, 12-38.

Loma 2002. - Лома, Александар. 2002. Пракосово. Словенски и индоевропски корени српске епике. Београд : Балканолошки институт, САНУ [Loma, Aleksandar. 2002. Prakosovo. Slovenski $i$ indoevropski koreni srpske epike. Beograd : Balkanološki institut, SANU].

Loma 2004. - Лома, Александар. 2004. „Димом у небо, Обред спаљивања мртвих у старим и традиционалним културама. Његово осмишљење у есхатолошким представама индоевропских народа, са посебним освртом на паганске Словене“. Кодови словенских култура 9 - Смрт: 7-64 [Loma, Aleksandar. 2004. „Dimom u nebo, Obred spaljivanja mrtvih u starim i tradicionalnim kulturama. Njegovo osmišljenje $u$ eshatološkim predstavama indoevropskih naroda, sa posebnim osvrtom na paganske Slovene“. Kodovi slovenskih kultura 9 - Smrt: 7-64].

Loma 2005. - Лома, Александар. 2005. „Стара словенска религија, један поглед из компаративног угла“. Зборник Матище српске за књижевност и језик 53, 1-3: 9-27 [Loma, Aleksandar. 2005. „Stara slovenska religija, jedan pogled iz komparativnog ugla“. Zbornik Matice srpske za književnost i jezik 53, 1-3: 9-27].

Loma 2008. - Лома, Александар. 2008. „Вулканологија и митологија“. Кодови словенских култура 10 - Ватра: 262-299 [Loma,Aleksandar. 2008. „Vulkanologija i mitologija“. Kodovi slovenskih kultura 10 Vatra: 262-299]. 
Mallory \& Adams. 2006. The Oxford Introduction to Proto-Indo-European and the Proto-Indo-European World. Oxford : Oxford University Press.

Marjanović 2017. - Марјановић, Саша. 2017. Поредбене фраземе са компонентом сотте/као у француском и српском језику. Докторска дисертација. Универзитет у Београду - Филолошки факултет [Marjanović, Saša. 2017. Poredbene frazeme sa komponentom comme/kao u francuskom i srpskom jeziku. Doktorska disertacija. Univerzitet u Beogradu - Filološki fakultet].

Maslova 2007. - Маслова, Валентина А. 2007. Лингвокультурология. Москва : Издательский центр «Академия» [Maslova, Valentina A. 2007. Lingvokul'turologiîa. Moskva : Izdatel'skiǐ tsentr «Akademiîa»].

Melerovich \& Mokienko. 2008. - Мелерович, Алина М., Валериј М. Мокиенко. 2008. Семантическая структура фразеологических јединиц современного русского языка. Кострома : Костромской государственный университет имени Н. А. Некрасова [Melerovich, Alina M., Valerij M. Mokienko. 2008. Semanticheskaia struktura frazeologicheskikh jedinitș sovremennogo russkogo iāzyka. Kostroma : Kostromskoĭ gosudarstvennyı̆ universitet imeni N. A. Nekrasova].

Mokienko 1989. - Мокиенко, Валерий, М. 1989. Славянская фразеология. Москва : Высшая школа [Mokienko, Valeriı̌, M. 1989. Slavíanskaía frazeologiîa. Moskva : Vysshaîa shkola].

Mokienko 2007. - Мокиенко, Валерий, М. 2007. Образы русской речи, Историко-этимологические очерки фразеологии. Москва : Флинта/Наука [Mokienko, Valeriǐ, M. 2007. Obrazy russkǒ̆ rechi, Istoriko-ètimologicheskie ocherki frazeologii. Moskva : Flinta/Nauka].

Mršević-Radović 1987. - Мршевић-Радовић, Драгана. 1987. Фразеолошке глаголско-именичке синтагме у савременом српскохрватском језику. Београд : Филолошки факултет [Mršević-Radović, Dragana. 1987. Frazeološke glagolsko-imeničke sintagme u savremenom srpskohrvatskom jeziku. Beograd : Filološki fakultet].

Mršević-Radović 2001. - Mršević-Radović, Dragana. 2001 „O strahu u srpskoj frazeologiji". U Język, literatura i kultura Słowian dawniej $i$ dziś. III. Linguaria, Seria Filologia Słowianska, № 5, 125-131. Poznań : Wydavniczstvo naukowe UAM.

Mršević-Radović 2014. - Мршевић-Радовић, Драгана. 2014. Фразеологија и национална култура. Друго издање. Београд : Друштво за српски језик и књижевност Србије [Mršević-Radović, Dragana. 2014. Frazeologija i nacionalna kultura. Drugo izdanje. Beograd : Društvo za srpski jezik i književnost Srbije].

Müller 1878. - Müller, Max. 1878. Comparative mythology. London : George Routledge and Sons, Limited / New York : E. P. Dutton and CO.

Nodilo 1981. - Nodilo, Natko. 1981. Stara vjera Srba i Hrvata. Split : Logos.

Pavlović 2009. - Павловић, Слободан. 2009. Старосрпска зависна реченица од XII до XV века. Сремски Карловци / Нови Сад : Издавачка књижарница Зорана Стојановића [Pavlović, Slobodan. 
2009. Starosrpska zavisna rečenica od XII do XVveka. Sremski Karlovci / Novi Sad : Izdavačka knjižarnica Zorana Stojanovića].

Pavlović 2013. - Павловић, Слободан. 2013. Узроции и механизми синтаксичких промена у српском језику. Сремски Карловци / Нови Сад : Издавачка књижарница Зорана Стојановића [Pavlović, Slobodan. 2013. Uzroci i mehanizmi sintaksičkih promena u srpskom jeziku. Sremski Karlovci / Novi Sad : Izdavačka knjižarnica Zorana Stojanovića].

Pavlović 2004. - Павловић, Тања. 2004. Живот и смрт у језику и култури (на руском и српском материјалу). Београд : Чигоја штампа [Pavlović, Tanja. 2004. Život $i$ smrt u jeziku i kulturi (na ruskom $i$ srpskom materijalu). Beograd : Čigoja štampa].

Petchenko 2008. - Петченко, Людмила. 2008. „Русские диалектные наименования ритуального и бытового огня“. Кодови словенских култура 10 - Ватра: 158-171 [Petchenko, Lîudmila. 2008. „Russkie dialektnye naimenovaniîa ritual'nogo i bytovogo ognîa“. Kodovi slovenskikh kultura 10 - Vatra: 158-171].

Potebnía 1989. - Потебня, Александр А. 1989. Слово и миф. Москва : Правда [Potebnía, Aleksandr A. 1989. Slovo i mif. Moskva : Pravda].

Telî̃a 1996. - Телия, Вероника Н. 1996. Русская фразеология: семантический, прагматический и лингвокультурологический аспекты. Москва : Школа „Языки русской культуры“ [Teliîa, Veronika N. 1996. Russkaiā frazeologiiā: semanticheskiŭ, pragmaticheskǐ i lingvokul'turologicheskiı̆ aspekty. Moskva : Shkola „Fazyki russkoĭ kul'tury"].

Tolstoj 1995. - Толстој, Никита И. 1995. Језик словенске културе. Ниш : Просвета [Tolstoj, Nikita I. 1995. Jezik slovenske kulture. Niš : Prosveta].

Trebješanin 1990. - Требјешанин, Жарко. 1990. „Поговор“. У Ватра у обичајима и животу српског народа, Сима Тројановић, 403-441. Београд : Просвета [Trebješanin, Žarko. 1990. „Pogovor“. U Vatra u običajima i životu srpskog naroda, Sima Trojanović, 403-441. Beograd : Prosveta].

Trojanović 1990. - Тројановић, Сима. 1990. Ватра у обичајима и животу српског народа. Београд : Просвета [Trojanović, Sima. 1990. Vatra u običajima i životu srpskog naroda. Beograd : Prosveta].

Vučković 2013. - Вучковић, Марија. 2013. Континуанте прасловенских основа " $g ъ b-$, "gyb-, *gub- у српском језику. Докторска дисертација. Универзитет у Београду - Филолошки факултет [Vučković, Marija. 2013. Kontinuante praslovenskih osnova *gzb-, "gyb-, *gub-u srpskom jeziku. Doktorska disertacija. Univerzitet u Beogradu - Filološki fakultet].

Vulović 2015. - Вуловић, Наташа. 2015. Српска фразеологија и религија. Лингвокултуролошка истраживања. Београд : Институт за српски језик САНУ [Vulović, Nataša. 2015. Srpska frazeologija $i$ 
religija. Lingvokulturološka istraživanja. Beograd : Institut za srpski jezik SANU].

Walter \& Mokienko. 2018.„Urslawische Phraseologie: Mythos oder Legende?“, Deutsche Beiträge zum 16. Internationalen Slavistenkongress Belgrad 2018 (Herausgegeben von Sebastian Kempgen, Monika Wingender und Ludger Udolph), 331-340. Wiesbaden : Harrassowitz Verlag.

Wierzbicka 1996. Semantics, Primes and Universals. Oxford : Oxford University Press.

Zykova 2015. - Зыкова, Ирина В. 2015. Концептосфера культуры и фразеология. Теория и методы лингвокультурологического изучения. Москва : Ленанд [Zykova, Irina V. 2015. Kontseptosfera kul'tury $i$ frazeologiia. Teoriia $i$ metody lingvokul'turologicheskogo izucheniia. Moskva : Lenand].

\author{
Katarina Begović \\ Univerza v Beogradu \\ Filološka fakulteta \\ Srbija \\ katarina.v.begovic@gmail.com
}

\title{
PAZITI SE (BATI SE) KOGA/ČESA KAKOR ŽIVEGA OGNJA: SRBSKO-SLOVENSKE VZPOREDNICE IN SPLOŠNI SLOVANSKI KONTEKST
}

V prispevku je obravnavan frazeologem paziti se (bati se) koga/česa kakor živega ognja v slovanskih jezikih, s posebnim poudarkom na srbskem in slovenskem kontekstu. Korpus je ekscerpiran iz različnih splošnih in frazeoloških leksikografskih virov. Glede na diahrono usmeritev raziskave so bili uporabljeni tako sodobni kot zgodovinski slovarji. Na podlagi ekscerpiranega gradiva in dosedanjih metodoloških postopkov za ugotavljanje starosti frazeologemov je mogoče domnevati, da je ta frazeološka enota podedovana iz praslovanskega jezika. Metodologija strukturno-semantičnega modeliranja predlaga motivacijsko podlago, ki je predmet frazeologizacije. Obravnavane so posebnosti srbskega in slovenskega korpusa glede na druge slovanske jezike. Posebna pozornost je v članku usmerjena na leksema »oganj« in »vatra« (ogenj) ter različice besedne zveze »živi ogenj«, ki predstavljajo motivacijo analizirane frazeološke enote.

Ključne besede: paziti se (bati se) koga/česa kakor živega ognja, živi ogenj / živa vatra, diahrona frazeologija, rekonstrukcija, strukturnosemantično modeliranje 
Katarina Begović

University of Belgrade

Faculty of Philology

Serbia

katarina.v.begovic@gmail.com

BOJATI SE (PLAŠITI SE, ČUVATI SE, BEŽATI OD) KOGA/

$\check{C} E G A K A O(O D)<\check{Z} I V O G>O G N J A(<\check{Z} I V E>V A T R E)$ ('TO

BE AFRAID OF (TO BE SCARED OF, TO BEWARE OF, TO

RUN FROM) SOMEONE/SOMETHING AS IF IT WERE A <LIVING> BLAZE (<LIVING> FIRE)'): SERBIAN-SLOVENIAN PARALLELS AND A GENERAL SLAVIC CONTEXT

The paper deals with a well-known phraseologism in Slavic languages - bojati se (plašiti se, čuvati se, bežati od) koga/čega kao (od) <živog> ognja (<žive> vatre) ('to be afraid of (to be scared of, to beware of, to run from) someone/something as if it were a <living> blaze (a <living> fire)'), with a special focus on the its usage in Serbian and Slovenian languages. The corpus for the study has been excerpted from a variety of lexicographic sources, both general and phraseological. Keeping in mind the diachronic nature of this research, both modern and historical dictionaries were consulted. Based on the excerpted material and current methodological procedures for determining the age of phraseologisms, it is believed that this particular phraseological unit could have been passed down from the Proto-Slavic language. Relying on the methodology of structural-semantic modeling, a motivational basis liable to phraseologization is suggested. The specific features of the Serbian and Slovenian corpus are also studied in regard to other Slavic languages. Special attention is paid to lexemes oganj ('blaze') and vatra ('fire') and syntagms živi oganj ('living blaze') and živa vatra ('living fire'), which are discussed as the motivation behind the analyzed phraseological unit.

Keywords: bojati se (plašiti se, čuvati se, bežati od) koga/čega kao (od) <živog> ognja (<žive> vatre) ('to be afraid of (to be scared of, to beware of, to run from) someone/something as if it were a <living> blaze (a <living> fire)'), živi oganj ('living blaze') / živa vatra ('living fire'), diachronic phraseology, reconstruction, structural-semantic modeling

Primljeno / Prejeto: 30. 06. 2020.

Prihvaćeno / Sprejeto: 04. 12. 2020. 